J. Dairy Sci. 96:1499-1510

http://dx.doi.org/10.3168/jds.2012-5493

(C) American Dairy Science Association ${ }^{\circledR}, 2013$.

\title{
Unraveling the microbiota of teat apices of clinically healthy lactating dairy cows, with special emphasis on coagulase-negative staphylococci
}

\author{
G. Braem, ${ }^{*}$ S. De Vliegher,† B. Verbist,‡ V. Piessens,§ E. Van Coillie,§ L. De Vuyst, ${ }^{*}$ and F. Leroy ${ }^{* 1}$ \\ ${ }^{*}$ Research Group of Industrial Microbiology and Food Biotechnology, Faculty of Sciences and Bio-engineering Sciences, \\ Vrije Universiteit Brussel, Pleinlaan 2, B-1050 Brussels, Belgium \\ †M-team and Mastitis and Milk Quality Research Unit, Department of Reproduction, Obstetrics and Herd Health, \\ Faculty of Veterinary Medicine, Ghent University, Salisburylaan 133, B-9820 Merelbeke, Belgium \\ $\ddagger$ Ministry of the Flemish Community, Institute for Agriculture and Fisheries Research, Technology and Food Science Unit, \\ Agricultural Engineering Research Area, Van Gansberghelaan 115 bus 1, B-9820 Merelbeke, Belgium \\ §Ministry of the Flemish Community, Institute for Agriculture and Fisheries Research, Technology and Food Science Unit, \\ Food Safety Research Area, Brusselsesteenweg 370, B-9090 Melle, Belgium
}

\section{ABSTRACT}

Swab samples $(\mathrm{n}=72)$ obtained from the teat apex of lactating dairy cows without visual signs of inflammation $(\mathrm{n}=18)$ were gathered on 2 well-managed Flemish dairy herds (herds 1 and 2) during the same month to assess the bacterial diversity of teat apices before milking. A combination of both culture-dependent [plating and (GTG) $)_{5}$ PCR fingerprinting of the colonies] and culture-independent [denaturing gradient gel electrophoresis (PCR-DGGE)] techniques indicated that the teat apices contain a wide diversity of bacterial genera. Despite a low bacterial load, 20 bacterial genera of 3 phyla (Actinobacteria, Firmicutes, and Proteobacteria) were present. The most prevalent bacteria were the coagulase-negative staphylococci (CNS), encompassing a total of 15 species, which were identified to the species level using a combination of $(\mathrm{GTG})_{5}$-PCR fingerprinting, gene sequencing (16S ribosomal RNA and rpoB genes), and a novel PCR-DGGE technique based on the tuf-PCR amplicon. Overall bacterial diversity did not differ significantly between the herds or between noninfected and subclinically infected quarters in herd 1. In herd 1, borderline significant lower CNS species diversity was found on teat apices of noninfected quarters compared with subclinically infected quarters. The most prevalent CNS species were Staphylococcus haemolyticus and Staphylococcus equorum in both herds and Staphylococcus carnosus in herd 2.

Key words: bacterial species diversity, coagulasenegative staphylococci, teat apex, udder health

Received March 1, 2012.

Accepted November 11, 2012.

${ }^{1}$ Corresponding author: fleroy@vub.ac.be

\section{INTRODUCTION}

Mastitis, or inflammation of the mammary gland, remains one of the most costly diseases for the dairy farmer (Huijps et al., 2009). An IMI, potentially leading to mastitis, occurs upon passage of bacteria from the teat canal into the udder. Although the keratin plug in the teat canal offers a primary defense against invading bacteria, $60 \%$ of teat canals of heifers are already open $60 \mathrm{~d}$ before parturition (Krömker and Friedrich, 2009). Six weeks into the dry period, up to $20 \%$ of the teats have not closed (Dingwell et al., 2002). In lactating cows, the sphincter muscles of the teat canal remain dilated for 1 to $2 \mathrm{~h}$ after milking, imposing a risk of bacterial infection by skin-colonizing, contagious, and environmental bacteria (Sieber and Farnsworth, 1981; Fox and Norell, 1994; Neijenhuis et al., 2000). Bacteria that have accumulated on the teat apex between milking rounds are the most likely to enter the mammary gland. Such bacteria may also end up in the milk and influence both its safety and processing (Verdier-Metz et al., 2012). Hence, a better understanding of the composition of the teat apex microbiota is needed.

The microbiology of the teat apex has previously been analyzed mostly with culture-dependent methods and the teat apex is known to carry a microbiota that includes both skin-associated bacteria (e.g., CNS) and mastitis-causing pathogens (e.g., Streptococcus agalactiae and Staphylococcus aureus; Woodward et al., 1987). However, Staph. aureus strains located on the teat apex may differ from strains found in the milk (Zadoks et al., 2002). Although the precise consequence of a continuous presence of CNS on the teat apex is under discussion, studies indicate that this type of colonizing bacteria and the time of colonization are relevant for udder health (Roberson et al., 1994; De Vliegher et al., 2003; Krömker and Friedrich, 2009; Piepers et al., 2011). Recently, a culture-independent analysis of 
the teat apices of clinically infected cows revealed wide bacterial species diversity (Braem et al., 2012).

Currently, CNS are the most frequently isolated group of bacteria in almost all mastitis-related surveys (Pitkälä et al., 2004; Piepers et al., 2007; Schukken et al., 2009). In the past, these bacteria were considered of limited importance for udder health and were thus classified as minor pathogens (Taponen et al., 2006). Although the effect of CNS on the SCC of milk is smaller than the effect of major pathogens (Supré et al., 2011), the prevalence among cows of IMI caused by CNS may vary between 6 and 27\% (Djabri et al., 2002). Further, CNS have been reported to cause cases of (mild) clinical mastitis (Schukken et al., 2009). Finally, reports indicate the presence of penicillin resistance in CNS in older cows (Rajala-Schultz et al., 2004). Although these findings suggest undesired properties associated with CNS, heifers with a CNS infection at calving have been reported to out-produce noninfected herd mates during first lactation and to have a lower incidence of clinical mastitis (Piepers et al., 2010). These seemingly conflicting results indicate that more research is needed to study the diverse group of CNS in more detail.

As a follow-up of a previous study that investigated the total microbiota of clinically infected cows (Braem et al., 2012), the aim of the present paper was to characterize the diversity of bacterial species present on the teat apices of clinically healthy lactating dairy cows, with a focus on CNS because of their suggested role in udder health. A culture-dependent method, with molecular identification of the isolates through (GTG) $)_{5}$-PCR fingerprinting, and a culture-independent method-denaturing gradient gel electrophoresis (DGGE) of PCR amplicons 16S rRNA (V6-V8)-PCR and tuf-PCR - were used in a complementary way to maximize bacterial coverage.

\section{MATERIALS AND METHODS}

\section{Sampling and Infection Status of Quarters}

Samples were taken from 18 clinically healthy lactating Holstein-Friesian cows in 2 Flemish dairy herds (herds 1 and 2) during the same month (April 2009). Herd 1 consisted of 87 cows characterized by an average milk production of $9,955 \mathrm{~kg}$ of milk per cow per year and an average bulk milk SCC of 202,000 cells/mL, whereas herd 2 consisted of 63 cows characterized by an average milk production of $10,372 \mathrm{~kg}$ of milk per cow per year and an average bulk milk SCC of 175,000 cells/mL. Lactating cows from both herds were milked twice a day (approximately every $12 \mathrm{~h}$ ) and subjected to postmilking teat dipping, using an iodine disinfec- tant (Blockade; DeLaval, Drongen, Belgium), implying an average of $12 \mathrm{~h}$ between last dip and sampling.

Immediately before milking, the teat apices $(\mathrm{n}=72)$ from 8 (herd 1) and 10 (herd 2) cows were sampled using a sterile swab (Copan, Brescia, Italy), covering the area $\left( \pm 0.5 \mathrm{~cm}^{2}\right)$ around the teat orifice, as previously described (De Vliegher et al., 2003). One sterile swab was used for each teat, and contamination of the swab with milk was avoided. After sampling of the teat apex and removing some streams of milk, quarter milk samples were taken for bacteriological analysis, as previously described (Piepers et al., 2007; Dohoo et al., 2011). Briefly, $0.01 \mathrm{~mL}$ of each quarter milk sample was spread on a quadrant of a blood-esculin agar plate and incubated aerobically at $37^{\circ} \mathrm{C}$ for $36 \mathrm{~h} \pm 12 \mathrm{~h}$. A quarter was classified as infected when growth of at least one colony was detected (Dohoo et al., 2011). For all infected quarters included in this study, no clinical signs (e.g., redness and abnormal milk) were observed by the veterinarian performing the teat apex and milk samplings. Therefore, these quarters were labeled as "subclinically infected," whereas quarters that were not infected were designated "noninfected." The 8 sampled cows of herd 1 had 15 noninfected and 17 infected quarters; the 10 cows of herd 2 had 38 noninfected and 2 infected quarters. Swabs were transported to the laboratory under refrigeration and processed within $30 \mathrm{~h}$. Briefly, the tips of the swabs were suspended in $5 \mathrm{~mL}$ of sterile saline solution $[0.85 \%(\mathrm{wt} / \mathrm{vol}) \mathrm{NaCl}$ and $0.01 \%$ (wt/vol) Tween 80; VWR International, Darmstadt, Germany] and vortexed vigorously for $5 \mathrm{~min}$, yielding $5 \mathrm{~mL}$ of cell suspensions containing the bacteria under investigation (further referred to as bacterial swab samples). Each bacterial swab sample was analyzed in a culture-dependent and a culture-independent manner.

\section{Growth Media}

Bacterial cultivation was performed by plating on agar-containing growth media, including brain heart infusion (BHI; Oxoid, Basingstoke, UK) as a nonselective growth medium; de Man, Rogosa, Sharpe medium (MRS; Oxoid) for the growth of lactobacilli; MacConkey medium (McC; Oxoid) for the growth of gramnegative bacteria; medium 17 (M17; Oxoid) for the growth of streptococci; and mannitol salt agar (MSA; VWR International) for the growth of staphylococci. All media contained 1.5\% (wt/vol) agar (Oxoid), were prepared according to the manufacturers' guidelines, and were autoclaved at $121^{\circ} \mathrm{C}$ for $20 \mathrm{~min}$. Media were inoculated with $100 \mu \mathrm{L}$ of the bacterial swab samples and incubated at $37^{\circ} \mathrm{C}$ for 24 to $48 \mathrm{~h}$. Colony-forming units were enumerated and expressed per swabbed sur- 
face unit of teat apex $\left(\mathrm{cfu} / \mathrm{cm}^{2}\right)$. Next, around $10 \%$ of all colonies were systematically isolated, encompassing every distinctly different phenotype present. Finally, the isolated colonies were purified through successive streakings, and overnight broth cultures (BHI) of 390 isolates were stored at $-80^{\circ} \mathrm{C}$ in $2 \mathrm{~mL}$ of $\mathrm{BHI}$ containing $20 \%$ ( vol/vol) of glycerol.

\section{DNA Extraction}

For culture-dependent analysis, overnight BHI cultures $(2 \mathrm{~mL})$ of the stored isolates were centrifuged $(16,000 \times g$ for $10 \mathrm{~min})$. Then, DNA was extracted from the cell pellets using a Nucleospin 96 Tissue kit (Macherey-Nagel GmbH, Düren, Germany) according to the manufacturer's guidelines, applying an adjusted lysis procedure with $200 \mu \mathrm{L}$ of lysis solution [Tris- $\mathrm{HCl}$ (VWR International), $20 \mathrm{~m} M$; EDTA, $2 \mathrm{~m} M$; Triton X-100 (Sigma-Aldrich Chemie, Steinheim, Germany), 1 $\mathrm{g} / \mathrm{L}$; lysozyme (VWR International), $50 \mathrm{~g} / \mathrm{L}$; mutanolysin (Sigma-Aldrich Chemie), 500,000 U/L; pH 8.0], and incubation at $37^{\circ} \mathrm{C}$ for $1 \mathrm{~h}$, followed by addition of 25 $\mu \mathrm{L}$ of proteinase $\mathrm{K}$ solution $(28.9 \mathrm{~g} / \mathrm{L}$; VWR International) and incubation at $56^{\circ} \mathrm{C}$ for $1 \mathrm{~h}$. Concentrations of DNA were measured using a NanoDrop ND-2000 spectrophotometer (Thermo Scientific, Wilmington, $\mathrm{DE}$ ) and diluted to $50 \mathrm{ng} / \mu \mathrm{L}$.

For culture-independent analysis, the pellet obtained through centrifugation $\left(21,036 \times \mathrm{g}, 30 \mathrm{~min}, 4^{\circ} \mathrm{C}\right)$ from the bacterial swab samples $(4 \mathrm{~mL})$ was used for DNA extraction, which was carried out using a DNA extraction kit (NucleoSpin Tissue XS; Macherey-Nagel $\mathrm{GmbH}$ ) according to the manufacturer's guidelines, with an adjusted lysis step (see above) in $80 \mu \mathrm{L}$ of lysis solution $\left(37^{\circ} \mathrm{C}, 1 \mathrm{~h}\right)$, followed by addition of $8 \mu \mathrm{L}$ of proteinase $\mathrm{K}$ solution $\left(56^{\circ} \mathrm{C}, 1 \mathrm{~h}\right)$. After purification, DNA was collected in a final volume of $20 \mu \mathrm{L}$.

\section{Culture-Dependent Analysis}

The (GTG) $)_{5}$ PCR fingerprinting of bacterial DNA was performed using the single oligonucleotide primer
$(\mathrm{GTG})_{5}$ (Tables 1 and 2). The obtained fingerprints were clustered to allow classification and identification of CNS isolates using a validated in-house library (Braem et al., 2011). As such, it was possible to dereplicate the totality of fingerprints into representative CNS isolates per cluster. Clustering similarity was based on the Pearson product-moment correlation coefficient, and a dendrogram was constructed using the unweighted pair group method with arithmetic average (UPGMA) clustering algorithm (Braem et al., 2011). Isolates with unknown (GTG) $)_{5}$ PCR fingerprints (i.e., not matching any fingerprints present in the library) were identified by $16 \mathrm{~S}$ rRNA gene sequencing (Tables 1 and 2). The sequencing results were evaluated using basic local alignment search tool (BLAST) analysis to determine the nearest known relatives in the National Center for Biotechnology Information database (http:// www.ncbi.nlm.nih.gov/BLAST), taking into account a minimum of $97 \%$ identity as a limit for identification on genus level of all isolates. If the $16 \mathrm{~S}$ rRNA gene sequencing identified the isolate as a member of the genus Staphylococcus (Zadoks and Watts, 2009), a next step was applied to elucidate the species level. As such, staphylococcal species determination was based on a minimum identity of $97 \%$ via rpoB gene sequencing (Tables 1 and 2; Drancourt and Raoult, 2002).

\section{Culture-Independent Analysis}

The PCR-DGGE was performed using amplicons of 2 different primer sets (Tables 1 and 2). First, analysis of the bacterial communities was performed using $16 \mathrm{~S}$ rRNA (V6-V8)-PCR-DGGE with the primers eub-f933GC and eub-r1387, and excised bands were reamplified using the primers eub-f933 and eub-r1387 (Table 1). Second, the group-selective amplification of staphylococci was performed using a newly developed method based on tuf-PCR-DGGE with the primers tuf-F-GC and tuf-R, whereas excised bands were re-amplified using the primers tuf-F and tuf-R. The PCR conditions

Table 1. Primers used for culture-dependent and culture-independent microbiological analyses

\begin{tabular}{lll}
\hline Primer & Sequence & Reference \\
\hline GC clamp & 5'-CGCCCGCCGCGCGCGGCGGGCGGGGCGGGGCACGGGGG-3' & Vasilopoulos et al. (2008) \\
eub-f933 & 5'-GCACAAGCGGTGGAGCATGTGG-3' & Iwamoto et al. (2000) \\
eub-f933-GC & 5'-GC-Clamp-GCACAAGCGGTGGAGCATGTGG-3' & Kawai et al. (2002) \\
eub-r1387 & 5'-GCCCGGGAACGTATTCACCG-3' & Iwamoto et al. (2000) \\
rpoB-F & 5'-AACCAATTCGTATIGGTTT-3' & Drancourt and Raoult (2002) \\
rpob-R & 5'-CCGTCCCAAGTCATGAAAC-3' & Drancourt and Raoult (2002) \\
tuf-F & 5'-GCCAGTTGAGGACGTATTCT-3' & Heikens et al. (2005) \\
tuf-F-GC & 5'-GC-Clamp-GCCAGTTGAGGACGTATTCT-3' & This study \\
tuf-R & 5'-CCATTTCAGTACCTTCTGGTAA-3' & Heikens et al. (2005) \\
6S-rDNA-1 & 5'-AGAGTTTGATCCTGGCTGAG-3' & Edwards et al.(1989) \\
16S-rDNA-2 & 5'-AAGGAGGTGATCCAGCCGCA-3' & Edwards et al.(1989) \\
(GTG) $)_{5}$ & 5'-GTGGTGGTGGTGGTG-3' & Gevers et al. (2001) \\
\hline
\end{tabular}


and denaturing gradient of the tuf-PCR-DGGE analysis were optimized using a set of 22 Staphylococcus field isolates previously gathered on the same dairy farms (1 isolate of Staph. arlettae, 3 of Staph. auricularis, 2 of Staph. capitis ssp. urealyticus, 1 of Staph. chromogenes, 4 of Staph. cohnii ssp. cohnii, 1 of Staph. equorum ssp. equorum, 5 of Staph. hemolyticus, 1 of Staph. hominis ssp. hominis, 1 of Staph. kloosii, 2 of Staph. saprophyticus ssp. saprophyticus, 1 of Staph. simulans, and 1 of Staph. succinus ssp. succinus), obtained from a bovine environment and previously identified through $(\mathrm{GTG})_{5}$-PCR fingerprinting and rpoB gene sequencing (Braem et al., 2011). Also, previously gathered teat apex communities from the same dairy farms and with a high load of staphylococci were used to optimize the method. The PCR mastermix contained $5 \mu \mathrm{L}$ of $10 \times$ buffer (Roche, Mannheim, Germany), $2.5 \mu \mathrm{L}$ of $0.1 \mathrm{mg} /$ mL BSA albumin (Acros Organics, Geel, Belgium), 2.5 $\mu M$ deoxynucleotide triphosphates (dNTP; Fermentas GmbH, St. Leon-Rot, Germany), 2 U of Taq polymerase (Roche), $3 \mu \mathrm{L}$ of the DNA template, and $2 \mu \mathrm{L}$ of $5 \mu M$ forward (with GC-clamp) and reverse primer each (Sigma-Aldrich, St. Louis, MO). Amplicons were loaded on a 1-mm-thick polyacrylamide gel of $160 \mathrm{~mm} \times 160 \mathrm{~mm}$ (6\% polyacrylamide-bisacrylamide; Bio-Rad, Hercules, CA) in a Dcode universal mutation detection system (Bio-Rad), using a denaturing gradient from 35 to $70 \%$ for $16 \mathrm{~S}$ rRNA (V6-V8)-PCR-DGGE and 25 to $60 \%$ for tuf-PCR-DGGE, consisting of urea and formamide [100\% denaturation corresponded to $7 \mathrm{~mol} / \mathrm{L}$ urea and $40 \%$ (wt/vol) formamide]. For electrophoresis, a constant temperature of $60^{\circ} \mathrm{C}$ and a voltage of $70 \mathrm{~V}$ were applied for $16 \mathrm{~h}$ in a tank filled with $1 \times$ Tris-acetate EDTA buffer (40 mM Tris-acetate, $1 \mathrm{~m} M$ EDTA, pH 8.0). The gels were stained using ethidium bromide and the band patterns were converted to a tagged image file format (TIFF) using a ProXima AQ-4 imaging system (Isogen, De Meern, the Netherlands). For identification, bands were excised from the gels and the template DNA for re-amplification was extracted by submerging the excised bands in $30 \mu \mathrm{L}$ of sterile ultrapure water, allowing diffusion overnight. Re-amplification of the bands was performed with a mastermix containing 5 $\mu \mathrm{L}$ of $10 \times$ buffer (Roche), $2.5 \mu \mathrm{L}$ of $0.1 \mathrm{mg} / \mathrm{mL}$ BSA (Acros Organics), $2.5 \mu M$ dNTP (Fermentas GmbH), 2 $\mathrm{U}$ of $\mathrm{Taq}$ polymerase (Roche), $2 \mu \mathrm{L}$ of template DNA, and $2 \mu \mathrm{L}$ of $5 \mu \mathrm{M}$ forward and reverse primer each (Sigma-Aldrich). These PCR products were purified, qualitatively checked in an agarose gel $(1.4 \%$, wt/vol), and bidirectional sequencing was performed in a commercial facility (VIB Genetic Service Facility, Antwerp, Belgium). BioNumerics software version 5.10 (Applied Maths NV, Sint-Martens-Latem, Belgium) was used for processing of the DNA sequences and for the construc- 
tion of a consensus sequence. The sequencing results were evaluated using BLAST analysis to determine the nearest known relatives in the National Center for Biotechnology Information database.

\section{Data Analysis}

Data analysis was performed to detect whether the microbial presence and diversity on teat apices differed among the 2 herds, as well as between teat apices of noninfected and subclinically infected quarters from cows in herd 1 (not relevant for herd 2, having a very low prevalence of subclinically infected quarters). Four different outcome variables were constructed: (1) number of genera, reflecting overall microbial diversity [culture-dependent and culture-independent analysis (16S rRNA-PCR-DGGE and tuf-PCR-DGGE), count data]; (2) microbial presence on teat apices (all CNS species based on culture-dependent analysis, binary outcome); (3) microbial presence on teat apices (all CNS species based on culture-dependent and culture-independent analysis (tuf-PCR-DGGE), binary outcome]; and (4) number of CNS species, reflecting CNS diversity [based on culture-dependent and culture-independent analysis (tuf-PCR-DGGE), count data]. Multilevel logistic regression (outcomes 2 and 3 ) and Poisson regression (outcomes 1 and 4) models were fit, respectively, including a random cow effect to account for clustering of teats within quarters using MlwiN 2.16 (Rasbash et al., 2009), allowing for extra binomial or Poisson variation, respectively.

\section{RESULTS}

\section{Optimization of the tuf-PCR DGGE Method}

Optimization of the tuf-PCR DGGE method for the identification of staphylococci encompassed an evaluation of the migration position inside the gel of the DNA corresponding with 22 previously identified Staphylococcus field isolates gathered on the same dairy farms, excision of the corresponding DGGE bands, and confirmation that the excised bands allowed identification of the original species. The DNA of each species migrated to a unique position inside the gel, with the exception of Staph. haemolyticus, for which different positions were found (Figure 1). The analysis of 10 swab samples from teat apices with a high staphylococcal load led to the excision of 17 bands from distinguishable migration positions in the gel. Whereas the DNA of 3 bands failed to re-amplify, 14 bands could be associated with 9 different Staphylococcus species: Staph. haemolyticus (100\% nucleotide similarity with JCSC1435, NCBI entry AP006716.1), Staph. chromogenes (99\% similarity with ATCC 43764, NCBI entry EU652790.1), Staph. capitis ssp. capitis (99\% similarity with CCM 2734, NCBI entry HM352920.1), Staph. epidermidis (99\% similarity with CCM 2124, NCBI entry HM352922.1), Staph. saprophyticus ssp. bovis (100\% nucleotide similarity with CCM 4410, NCBI entry HM352934.1), Staph. cohnii ssp. cohnii (98\% similarity with CCM 2736, NCBI entry HM352938.1), Staph. arlettae (98\% similarity with DSM 20672, NCBI entry HM352954.1), Staph. equorum ssp. equorum (98\% similarity with DSM 20674, NCBI entry HM352959.1), and Staph. devriesei (100\% similarity with DSM 25293, NCBI entry FJ389243.1).

\section{Overall Bacterial Species Diversity on Teat Apices}

Culture-Dependent Analysis. The bacterial load of the different swab samples was, on average, low: MRS agar $=$ maximum of $6.2 \times 10^{3} \mathrm{cfu} / \mathrm{cm}^{2}$, average of $4.2 \times 10^{2} \mathrm{cfu} / \mathrm{cm}^{2} ;$ M17 agar $=$ maximum of $6.5 \times$ $10^{4} \mathrm{cfu} / \mathrm{cm}^{2}$, average of $2.5 \times 10^{3} \mathrm{cfu} / \mathrm{cm}^{2} ; \mathrm{McC}$ agar $=$ maximum of $7.0 \times 10^{4} \mathrm{cfu} / \mathrm{cm}^{2}$, average of $2.5 \times 10^{3}$ $\mathrm{cfu} / \mathrm{cm}^{2} ; \mathrm{MSA}=$ maximum of $8.9 \times 10^{3} \mathrm{cfu} / \mathrm{cm}^{2}$, average of $9.2 \times 10^{2} \mathrm{cfu} / \mathrm{cm}^{2}$; and BHI agar $=$ maximum of $1.7 \times 10^{4} \mathrm{cfu} / \mathrm{cm}^{2}$, average of $1.4 \times 10^{3} \mathrm{cfu} / \mathrm{cm}^{2}$.

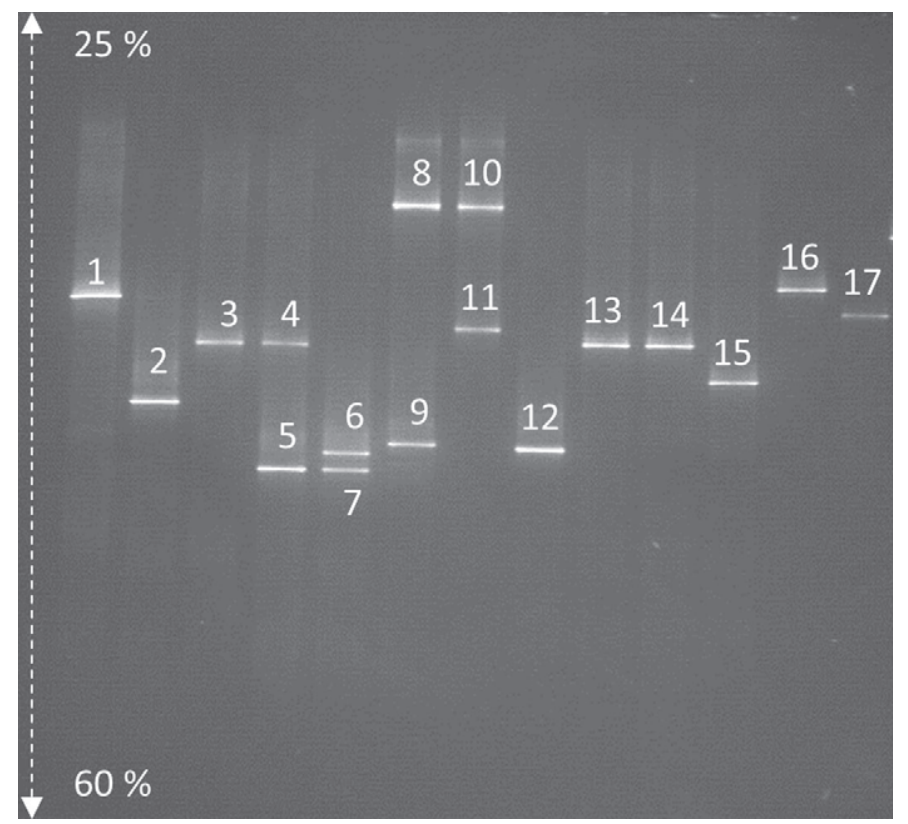

Figure 1. Migration positions of tuf-PCR amplicons in a 25 to $60 \%$ denaturing gradient during denaturing gradient gel electrophoresis: (1) Staphylococcus arlettae, (2) Staphylococcus auricularis, (3-4) Staphylococcus saprophyticus, $(5,7)$ Staphylococcus cohnii ssp. cohnii, (6) Staphylococcus equorum, $(8,10)$ Staphylococcus capitis, (9) Staphylococcus hominis, (11) Staphylococcus chromogenes, (12) Staphylococcus kloossii, (13-15) Staphylococcus hemolyticus, (16) Staphylococcus simulans, and (17) Staphylococcus succinus. 
In total, 390 isolates were identified through (GTG) $)_{5^{-}}$ PCR fingerprinting, of which 226 isolates were obtained from herd 1 and 164 isolates from herd 2. The strains identified belonged to 2 phyla, namely the Firmicutes $(\mathrm{n}=279)$ and the Actinobacteria $(\mathrm{n}=111)$. The Firmicutes isolates belonged to species from 10 genera: Aerococcus ( $\mathrm{n}=3)$, Bacillus $(\mathrm{n}=18)$, Brevibacillus ( $\mathrm{n}$ $=3)$, Enterococcus $(\mathrm{n}=4)$, Lactobacillus $(\mathrm{n}=1)$, Lysinibacillus $(\mathrm{n}=2)$, Oceanobacillus $(\mathrm{n}=1)$, Paenibacillus $(\mathrm{n}=8)$, Staphylococcus $(\mathrm{n}=229)$, and Weissella $(\mathrm{n}$ $=10$ ). The Actinobacteria isolates belonged to species of the genera Brevibacterium $(\mathrm{n}=3)$, Corynebacterium $(\mathrm{n}=11)$, Kocuria $(\mathrm{n}=76)$, and Micrococcus $(\mathrm{n}=21)$ (Tables 3 and 4 ).

The use of different media did not provide the intended selectiveness (Table 4). For instance, all applied growth media allowed for the cultivation of staphylococci. Indeed, $68.2,62.5,68.8,33.3$, and $54.6 \%$ of the total number of identified isolates on MRS, MSA, McC, M17, and BHI were staphylococci. Brain heart infusion, M17, and McC media allowed the identification of 8 , 11, and 10 genera, respectively, and MRS allowed the identification of 7 genera. The use of MSA permitted the identification of 10 Staphylococcus species (Table $5)$. However, this medium also allowed the growth of numerous other genera (Table 4).

Culture-Independent Analysis. Culture-independent analysis of the teat apex swabs revealed, after sequencing of the excised DGGE bands (representing V6-V8 targeted 16S rRNA PCR amplicons), the presence of 3 phyla: Firmicutes, Actinobacteria, and Proteobacteria. After consulting GenBank, the presence of the following bacterial taxa was suggested for the Firmicutes: Aerococcus viridans (99\% nucleotide similarity with GenBank accession number AY707778), Jeotgalicoccus coquina (98\% with GU295938), Lactobacillus fermentum (100\% with CP002033), and Staphylococcus species (97-99\% with HM218041). The Actinobacteria were represented by Corynebacterium coyleae (99\% with X96497) and Propionibacterium sp. (99\% with FN691981), whereas the Proteobacteria were represented by Burkholderia sp. (100\% with HQ231941), Psychrobacter immobilis (99\% with AJ309942), and Citrobacter freundii (99\% with AJ233431) or Serratia marcescens (99\% with NR028894). The latter 2 species could not be distinguished based on the sequenced DNA fragment.

\section{Staphylococcal Species Diversity on Teat Apices}

Culture-Dependent Analysis. Of all $(\mathrm{n}=390)$ purified isolates, 229 were identified as staphylococci, of which 116 and 113 were isolated from teat apices of cows of herd 1 and herd 2, respectively. The CNS isolates

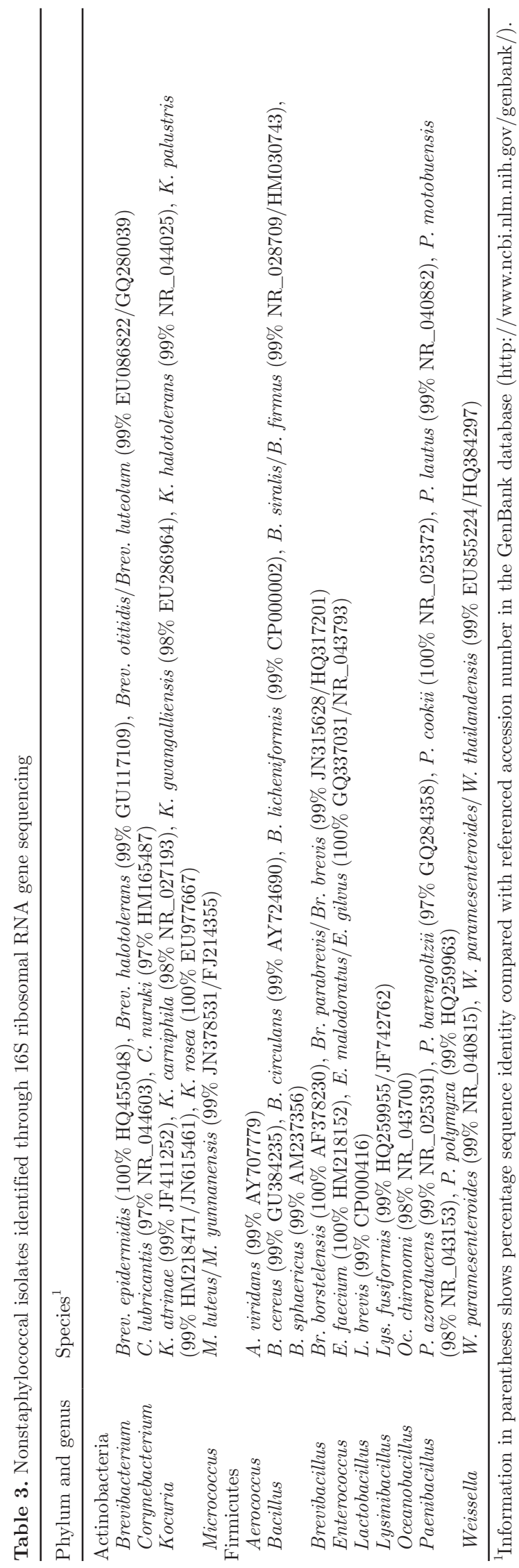


Table 4. Overview of the bacterial genera found on teat apices of 18 clinically healthy lactating cows from two dairy herds using culture-dependent and culture-independent microbiological methods

\begin{tabular}{|c|c|c|c|c|c|c|c|c|c|c|c|c|c|c|c|}
\hline \multirow[b]{4}{*}{ Genus } & \multirow{2}{*}{\multicolumn{7}{|c|}{ Culture-dependent analysis ${ }^{1}$}} & \multirow{2}{*}{\multicolumn{4}{|c|}{ Culture-independent analysis ${ }^{2}$}} & \multicolumn{4}{|c|}{ Combined analysis $^{3}$} \\
\hline & & & & & & & & & & & & $\mathrm{He}$ & d 1 & Her & d 2 \\
\hline & \multicolumn{5}{|c|}{ Quarters, \% $(\mathrm{n}=72)$} & \multirow{2}{*}{$\begin{array}{c}\text { Quarters, } \\
\quad \% \\
(\mathrm{n}=72)\end{array}$} & \multirow{2}{*}{$\begin{array}{l}\text { Cows, } \% \\
(\mathrm{n}=18)\end{array}$} & \multirow{2}{*}{\multicolumn{2}{|c|}{$\begin{array}{l}\text { Quarters, \% } \\
\frac{(\mathrm{n}=72)}{16 \mathrm{~S}} \\
\text { rRNA tuf }\end{array}$}} & \multirow{2}{*}{$\begin{array}{c}\text { Quarters, \% } \\
(\mathrm{n}=72)\end{array}$} & \multirow{2}{*}{$\begin{array}{l}\text { Cows, \% } \\
(\mathrm{n}=18)\end{array}$} & \multirow{2}{*}{$\begin{array}{l}\text { Noninfected } \\
\text { quarters, \% } \\
(\mathrm{n}=15)\end{array}$} & \multirow{2}{*}{$\begin{array}{l}\text { Subclinically } \\
\text { infected } \\
\text { quarters, \% } \\
(\mathrm{n}=17)\end{array}$} & \multirow{2}{*}{$\begin{array}{l}\text { Noninfected } \\
\text { quarters, \% } \\
(\mathrm{n}=38)\end{array}$} & \multirow{2}{*}{$\begin{array}{c}\text { Subclinically } \\
\text { infected } \\
\text { quarters, } \% \\
(\mathrm{n}=2)\end{array}$} \\
\hline & BHI & M17 & $\mathrm{McC}$ & MRS & MSA & & & & & & & & & & \\
\hline Aerococcus & 0 & 0 & 1 & 0 & 1 & 1 & 6 & 17 & 0 & 17 & 17 & 40 & 41 & 0 & 0 \\
\hline Bacillus & 7 & 8 & 3 & 4 & 1 & 22 & 72 & 0 & 0 & 0 & 0 & 13 & 35 & 21 & 0 \\
\hline Brevibacillus & 1 & 1 & 0 & 0 & 1 & 4 & 11 & 0 & 0 & 0 & 0 & 0 & 6 & 5 & 0 \\
\hline Brevibacterium & 0 & 1 & 1 & 0 & 1 & 3 & 11 & 0 & 0 & 0 & 0 & 0 & 12 & 0 & 0 \\
\hline Brochothrix & 0 & 0 & 0 & 0 & 0 & 0 & 0 & 0 & 6 & 6 & 11 & 13 & 0 & 3 & 50 \\
\hline Burkholderia & 0 & 0 & 0 & 0 & 0 & 0 & 0 & 4 & 0 & 4 & 6 & 20 & 0 & 0 & 0 \\
\hline Corynebacterium & 3 & 0 & 1 & 1 & 6 & 8 & 28 & 1 & 0 & 1 & 6 & 13 & 24 & 3 & 0 \\
\hline Enterococcus & 0 & 1 & 1 & 1 & 1 & 6 & 22 & 0 & 0 & 0 & 0 & 7 & 12 & 3 & 0 \\
\hline Jeotgalicoccus & 0 & 0 & 0 & 0 & 0 & 0 & 0 & 4 & 0 & 4 & 6 & 0 & 0 & 8 & 0 \\
\hline Citrobacter/Serratia & 0 & 0 & 0 & 0 & 0 & 0 & 0 & 49 & 0 & 49 & 61 & 73 & 65 & 29 & 100 \\
\hline Kocuria & 17 & 25 & 8 & 0 & 18 & 42 & 67 & 0 & 0 & 0 & 0 & 73 & 71 & 18 & 0 \\
\hline Lactobacillus & 0 & 0 & 0 & 1 & 0 & 1 & 6 & 29 & 0 & 29 & 56 & 27 & 29 & 29 & 100 \\
\hline Lysinibacillus & 1 & 1 & 0 & 0 & 0 & 3 & 11 & 0 & 0 & 0 & 0 & 0 & 0 & 5 & 0 \\
\hline Micrococcus & 8 & 8 & 4 & 0 & 3 & 22 & 61 & 0 & 0 & 0 & 0 & 13 & 24 & 24 & 50 \\
\hline Oceanobacillus & 0 & 1 & 0 & 0 & 0 & 1 & 6 & 0 & 0 & 0 & 0 & 0 & 6 & 0 & 0 \\
\hline Paenibacillus & 3 & 4 & 3 & 1 & 0 & 10 & 33 & 0 & 0 & 0 & 0 & 7 & 0 & 16 & 0 \\
\hline Propionibacterium & 0 & 0 & 0 & 0 & 0 & 0 & 0 & 18 & 0 & 18 & 22 & 27 & 0 & 21 & 50 \\
\hline Psychrobacter & 0 & 0 & 0 & 0 & 0 & 0 & 0 & 11 & 0 & 11 & 11 & 0 & 0 & 21 & 0 \\
\hline Staphylococcus & 36 & 24 & 33 & 26 & 36 & 61 & 89 & 64 & 49 & 83 & 94 & 93 & 100 & 97 & 100 \\
\hline Weissella & 0 & 1 & 1 & 1 & 1 & 1 & 6 & 0 & 0 & 0 & 0 & 0 & 6 & 0 & 0 \\
\hline
\end{tabular}

3. ${ }^{1}$ Culture-dependent analysis revealed the percentages of teat apices that yielded a culture-positive response for all listed genera per growth medium, and likewise for the overall

percentages of teat apices and cows for all media combined. BHI = brain heart infusion agar (nonselective medium); M17 = medium 17 (streptococci); McC = McConkey agar 을 (gram-negative bacteria); MRS = de Man, Rogosa, and Sharpe agar (lactobacilli); MSA = mannitol sugar agar (staphylococci).

兽. $\quad{ }^{2}$ Culture-independent analysis revealed the percentages of teat apices that yielded a positive signal for all listed genera using 16S ribosomal RNA (V6-V8)-PCR-denaturing gradient (N) gel electrophoresis (DGGE) or tuf-PCR-DGGE, and likewise for the overall percentages of teat apices and cows for the PCR-DGGE methods combined.

$\frac{\Gamma}{\Phi} \cdot \quad{ }^{3} \mathrm{~A}$ combination of culture-dependent and culture-independent analyses was used to list the percentages of teat apices that were positive for a certain genus, while differentiating between herds and infection status (noninfected and subclinically infected quarters) 
Table 5. Overview of the Staphylococcus species found on teat apices of 18 clinically healthy lactating cows from 2 dairy herds using culture-dependent and culture-independent microbiological methods

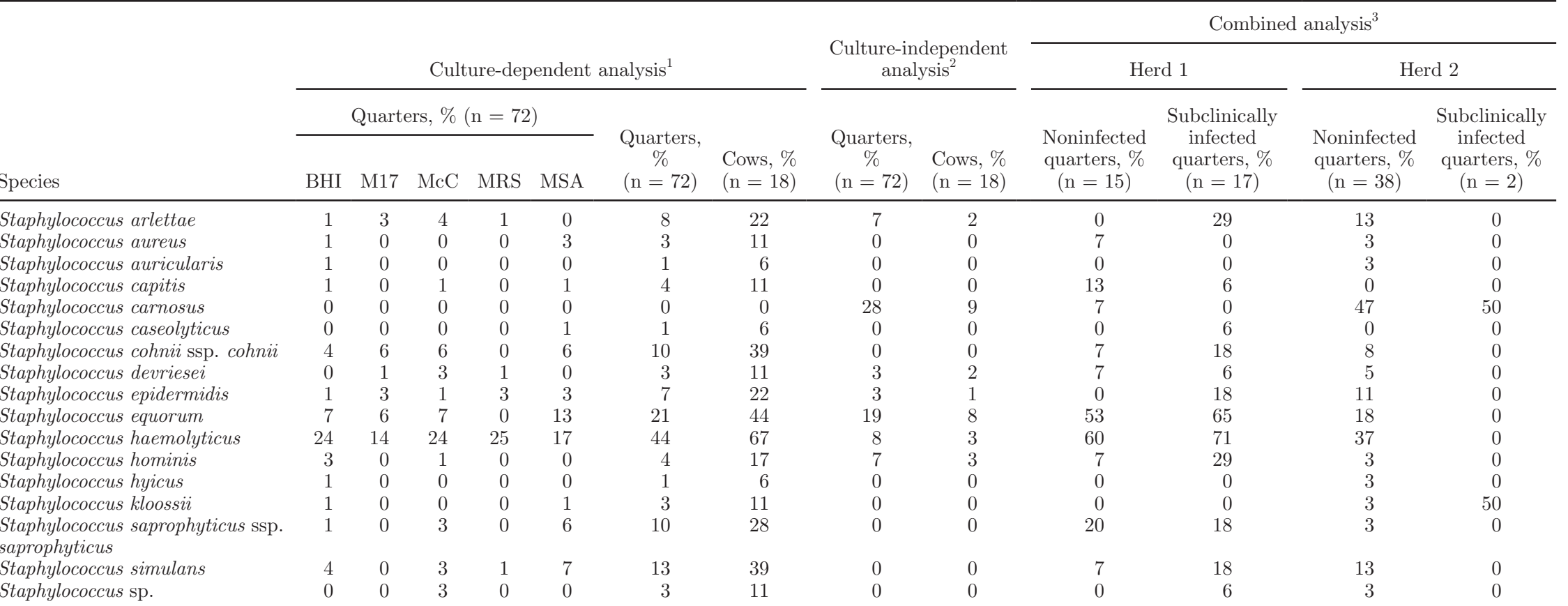

${ }^{1}$ Culture-dependent analysis revealed the percentages of teat apices that yielded a culture-positive response for all listed species per growth medium, and likewise for the overall percentages of teat apices and cows for all media combined. BHI = brain heart infusion agar (nonselective medium); M17 = medium 17 (streptococci); McC = McConkey agar (gram-negative bacteria); MRS = de Man, Rogosa, and Sharpe agar (lactobacilli); MSA = mannitol sugar agar (staphylococci).

${ }^{2}$ Culture-independent analysis revealed the percentages of teat apices and cows that yielded a positive signal for all listed species using tuf-PCR-denaturing gradient gel electrophoresis.

${ }^{3} \mathrm{~A}$ combination of culture-dependent and culture-independent analyses was used to list the percentages of teat apices that were positive for a certain species, while differentiating between herds and infection status (noninfected and subclinically infected quarters) 
were subdivided into 18 (GTG) - $_{5}$ PCR fingerprint types belonging to 15 species, of which Staph. haemolyticus was encountered most frequently $(\mathrm{n}=116)$. Eleven Staphylococcus species were encountered in herd 1 and 13 in herd 2. Staphylococcus haemolyticus and Staph. saprophyticus ssp. saprophyticus were characterized by 3 and 2 distinct (GTG) $)_{5}$ PCR fingerprints, respectively (Pearson correlation and UPGMA clustering similarity $<50 \%)$. For Staph. haemolyticus, different fingerprint types (I, II, and III) corresponded to 100, 15, and 3 isolates, respectively. For Staph. saprophyticus ssp. saprophyticus, fingerprint type I was isolated 6 times and fingerprint type II 3 times. Other Staphylococcus species included Staph. equorum $(\mathrm{n}=31)$, Staph. cohnii ssp. cohnii $(\mathrm{n}=21)$, Staph. simulans $(\mathrm{n}=11)$, Staph. devriesei $(\mathrm{n}=9)$, and Staph. arlettae $(\mathrm{n}=8)$. The remaining Staphylococcus species were isolated fewer than 8 times and are listed in Table 5 .

Culture-Independent Analysis. The staphylococcal species diversity was also determined by making use of tuf-PCR-DGGE. In total, 35 bands from 4 gels were excised from the tuf-PCR-DGGE gels and sequenced; 27 bands indicated the presence of species belonging to the Firmicutes: Brochothrix thermosphacta (99\% nucleotide similarity with GenBank accession number AB492875), Staph. carnosus (99\% similarity with AM295250), Staph. devriesei (99\% similarity with FJ389243), Staph. epidermidis (99\% similarity with HM032776), Staph. equorum (99\% similarity with EU652795), Staph. haemolyticus (99\% similarity with HM032764), and Staph. hominis ssp. hominis (99\% similarity with AF298802). The remaining 8 bands resulted in identity values $<88 \%$, which could represent staphylococci (similarity with EU652781, EU652813, and EU652805) and Enterococcus species (similarity with AF274722 and AF274736). However, these identities were too low to allow any certainty regarding genus level.

\section{Genera and Species Distribution Between Herds and Relation with Infection Status of the Quarters}

Using the combined results of the culture-dependent and culture-independent methods [both 16S rRNA (V6V8)-PCR-DGGE and tuf-PCR-DGGE], the occurrence of the bacterial genera and their distribution on teat apices among herds, cows, and quarters was described (Table 4). The culture-independent analysis revealed complementary information by additionally revealing the presence of Proteobacteria, Brochothrix and Jeotgalicoccus (Firmicutes), and Propionibacterium (Actinobacteria). Two genera, Oceanobacillus and Weissella, were encountered only once (one teat apex of one cow). In contrast, CNS species were encountered on all cows sampled, whereas species belonging to 5 other genera
(Bacillus, Citrobacter/Serratia, Kocuria, Lactobacillus, and Micrococcus) were present on over half of the cows sampled.

Using both culture-dependent and culture-independent data, significantly more $(P=0.033)$ genera were detected on teat apices from cows in herd 1 than in herd 2 (outcome variable 1). However, no significant difference was found when comparing the number of genera between the teat apices of noninfected quarters and the teat apices of subclinically infected quarters in herd 1 (outcome variable 1). Although Aerococcus was not encountered in herd 2, it was present on 40 and $41 \%$ of the noninfected and subclinically infected quarters of herd 1, respectively. Species belonging to Citrobacter/Serratia and Kocuria were present on over $60 \%$ of the noninfected and infected quarters of herd 1 . Staphylococci were present on 93 and $97 \%$ of the noninfected quarters in herd 1 and herd 2, respectively, and on $100 \%$ of the subclinically infected quarters in both herds. Overall, no significant differences were found when comparing the number of teat apices containing CNS in herds 1 and 2, and between the noninfected and subclinically infected quarters in herd 1 (outcome variables 2 and 3). The genera Burkholderia, Jeotgallicoccus, Lysinibacillus, Paenibacillus, and Psychrobacter were exclusively found on noninfected quarters, whereas Brevibacterium, Oceanobacillus, and Weissella were exclusively found on subclinically infected quarters.

Using a combination of culture-dependent analysis and tuf-PCR-DGGE, the distribution of individual Staphylococcus species on cows $(\mathrm{n}=18)$ and quarters (n = 72) was further characterized (Table 5). Three CNS species (Staph. carnosus, Staph. equorum, and Staph. haemolyticus) were present on more than half of the teat apices. Staphylococcus aureus was encountered on teats of 2 noninfected quarters. All other CNS species were found on fewer than $15 \%$ of the sampled teats. Using both culture-dependent and culture-independent data, no significant differences in the number of CNS species present on teat apices from cows between herds 1 and 2 were found (outcome variable 4). Noninfected quarters in herd 1 showed a borderline significant $(P=$ 0.058) lower number of CNS species on the teats compared with the subclinically infected quarters (outcome variable 4).

In both herds, Staph. haemolyticus and Staph. equorum were the principal species, whereas in herd 2, Staph. carnosus also prevailed. Staphylococcus haemolyticus was present on more than half of the teats of both noninfected and subclinically infected quarters of herd 1. On average, using combined culture-dependent and tuf-PCR-DGGE analysis, 2 CNS species were found on each quarter, yet 2 noninfected quarters carried up to 6 CNS species; both contained Staph. cohnii, Staph. 
epidermidis, and Staph. haemolyticus. Additionally, one of the quarters carried Staph. arlettae, Staph. carnosus, and Staph. devriesei, whereas the other quarter also carried Staph. equorum, Staph. hominis, and Staph. simulans.

\section{DISCUSSION}

A combination of culture-dependent and cultureindependent analyses was used to map the total bacterial species diversity on the teat apices of cows from 2 well-managed Flemish dairy herds, in which postmilking teat dipping was applied to prevent new IMI, as recommended by the National Mastitis Council (NMC, 2012). Despite frequent disinfection and good hygiene, a wide diversity of bacterial genera and species was uncovered. The most commonly present and frequently isolated microbiota on the teat apices were CNS, and only minor occurrences of other genera were found. For the particular data set and methodology applied in the present study, no significant differences in bacterial diversity on the teat apices per infection status were revealed.

The most striking observation was the frequent isolation and the common presence of CNS on teat apices (59\% of all isolates were CNS and $97.2 \%$ of all sampled teat apices carried CNS). To obtain a more detailed picture of the staphylococcal species diversity, this study also included a novel culture-independent approach, using a PCR-DGGE method based on previously validated group-specific primers for the amplification of the tuf gene in staphylococci (Heikens et al., 2005). This tuf-PCR-DGGE method allowed culture-independent identification of staphylococci to the species level, in contrast to $16 \mathrm{~S}$ rRNA-PCR-DGGE. Discrepancies were detected between the bacterial diversities uncovered using culture-dependent and culture-independent methods, which may be related to culture biases, low recovery of DNA from swab samples, PCR specificity, and detection limits. In general, higher bacterial species diversity was detected for CNS using culture-dependent analysis compared with culture-independent analysis. However, the additional detection of Staph. carnosus, a species only rarely associated with the teat apex skin or mastitis (Taponen et al., 2008), underlines the benefit of including a culture-independent analysis. The fact that Staph. carnosus was not found by the culturedependent analysis is surprising, because this species is able to grow on several of the media used in the current study.

Most isolates belonged to Staph. haemolyticus, a species that is not often identified as a causal agent of clinical mastitis in cows (Piessens et al., 2011) nor is it associated with high antibiotic resistance in a dairy context (Sampimon et al., 2011). However, Staph. haemolyticus is not uncommon on teat apices, as indicated by the present study, and has previously been recovered from milk of subclinically infected quarters (Thorberg et al., 2009; Piessens et al., 2011; Supré et al., 2011). Both Staph. simulans and Staph. epidermidis, 2 species that have previously been identified as possible causes of clinical and subclinical mastitis, were found on teats of both noninfected and subclinically infected quarters during the present study (Taponen et al., 2007; Gillespie et al., 2009; Thorberg et al., 2009). Additionally, in the current study, Staph. chromogenes and Staph. xylosus could not be isolated from healthy cows, although these 2 species have been identified as causes of IMI (Supré et al., 2011). Although an IMI with CNS is mostly due to the establishment of a single species into the udder (Supré et al., 2011), the present study demonstrated that the CNS microbiota lining the teat apex can be composed of a wide variety of species, 15 of which were reported here. On average, 2 CNS were found on each teat apex and up to 6 CNS species could be found on a single teat apex, possibly originating from the environment (Piessens et al., 2011). Co-habitation of CNS species might increase the risk of inter-species genetic exchange, including virulence factors and antibiotic resistances (Cooksey and Baldwin, 1985; Parsek and Singh, 2003). The latter is of particular concern, as a large variety of mobile genetic elements carrying the $m e c \mathrm{~A}$ gene have been uncovered in CNS (Zong et al., 2011; Tulinski et al., 2012).

With the exception of Staph. aureus, none of the major mastitis-related pathogens, such as Streptococcus uberis, Streptococcus dysgalactiae, or Streptococcus agalactiae, were detected on teats of the cows included in this study. Only a few Staph. aureus were found on noninfected quarters of single cows solely. This may be due to their absence from farms that house healthy, lactating dairy cows, the sampling strategy, the number of samples, or the implication of competition between CNS and more pathogenic species. Besides CNS, species belonging to the genera Bacillus, Citrobacter/ Serratia, Kocuria, Lactobacillus, and Micrococcus were isolated most frequently and were present on more than half of the teat apices of udders of the sampled cows. Most of these genera have previously been associated with bovine skin (Woodward et al., 1987), but have been reported as only infrequent causes of IMI (Jones and Turnbull, 1981; Holm et al., 2004; Pinzón-Sánchez and Ruegg, 2011). For instance, infections with Bacillus spp. do not necessarily result in a high milk SCC (Sampimon et al., 2009). However, the presence of Bacillus cereus may influence the processing of pasteurized milk (Magnusson et al., 2007). Most species belonging to genera other than those mentioned above were isolated 
from a limited number of teat apices, indicating a wide variety yet limited abundance. This was the case for species of Aerococcus, Brevibacillus, Brevibacterium, Jeotgalicoccus, Paenibacillus, and Weissella.

\section{CONCLUSIONS}

The microbiota present on the teat apices of clinically healthy lactating dairy cows (18 cows from 2 farms, 72 quarters for analysis) showed a low but diverse bacterial load and a limited number of prevailing species. Coagulase-negative staphylococci were present on nearly all sampled teat apices, and within this group, Staph. haemolyticus and Staph. equorum (both herds) and Staph. carnosus (herd 2) were found most frequently. The plurality of bacterial genera and wide overall species diversity indicates a rich bacterial ecosystem on teat apices before and after milkings. This study offers additional insights into the complexity of the microbial teat ecosystem and lays a basis for future unraveling of the relationship between the microorganisms that prevail on the teat apices and udder health. Although we found no evidence for an association between teat microbiota and udder health in this study, more insight into the teat microbiota may contribute to development of additional udder health management methods. Poor udder health is a major cause of economic loss and compromises animal welfare. However, the precise role of this complex teat apex microbiota, among which CNS are prevailing, remains to be elucidated.

\section{ACKNOWLEDGMENTS}

This study was supported by grants from the Research Council of the Vrije Universiteit Brussel and the Agency for Innovation by Science and Technology (IWT-Vlaanderen, Brussels, Belgium, grant no. 60714). The authors thank Wendie Vanheffen (Research Group of Industrial Microbiology and Food Biotechnology, Vrije Universiteit Brussel, Brussels, Belgium) for the help with DGGE and bacterial isolations.

\section{REFERENCES}

Braem, G., S. De Vliegher, K. Supré, F. Haesebrouck, F. Leroy, and L. De Vuyst. 2011. (GTG) $)_{5}$-PCR fingerprinting for the classification and identification of coagulase-negative Staphylococcus species from bovine milk and teat apices: A comparison of type strains and field isolates. Vet. Microbiol. 147:67-74.

Braem, G., S. De Vliegher, B. Verbist, M. Heyndrickx, F. Leroy, and L. De Vuyst. 2012. Culture-independent exploration of the teat apex microbiota of dairy cows reveals a wide bacterial species diversity. Vet. Microbiol. 157:383-390.

Cooksey, R. C., and J. N. Baldwin. 1985. Relatedness of tetracycline resistance plasmids among species of coagulase-negative staphylococci. Antimicrob. Agents Chemother. 27:234-238.
De Vliegher, S., H. Laevens, L. A. Devriese, G. Opsomer, J. L. M. Leroy, H. W. Barkema, and A. de Kruif. 2003. Prepartum teat apex colonization with Staphylococcus chromogenes in dairy heifers is associated with low somatic cell count in early lactation. Vet. Microbiol. 92:245-252.

Dingwell, R. T., T. F. Duffield, K. E. Leslie, G. P. Keefe, L. DesCoteaux, D. F. Kelton, K. D. Lissemore, Y. H. Schukken, P. Dick, and R. Bagg. 2002. The efficacy of intramammary tilmicosin at dryingoff, and other risk factors for the prevention of new intramammary infections during the dry period. J. Dairy Sci. 85:3250-3259.

Djabri, B., N. Bareille, F. Beaudeau, and H. Seegers. 2002. Quarter milk somatic cell count in infected dairy cows: A meta-analysis. Vet. Res. 33:335-357.

Dohoo, I. R., J. Smith, S. Andersen, D. F. Kelton, and S. Godden. 2011. Diagnosing intramammary infections: Evaluation of definitions based on a single milk sample. J. Dairy Sci. 94:250-261.

Drancourt, M., and D. Raoult. 2002. RpoB gene sequence-based identification of Staphylococcus species. J. Clin. Microbiol. 40:13331338.

Edwards, U., T. Rogall, H. Blocker, M. Emde, and E. C. Bottger. 1989. Isolation and direct complete nucleotide determination of entire genes. Characterization of a gene coding for $16 \mathrm{~S}$ ribosomal RNA. Nucleic Acids Res. 17:7843-7853.

Fox, L. K., and R. J. Norell. 1994. Staphylococcus aureus colonization of teat skin as affected by postmilking teat treatment when exposed to cold and windy conditions. J. Dairy Sci. 77:2281-2288.

Gevers, D., G. Huys, and J. Swings. 2001. Applicability of rep-PCR fingerprinting for identification of Lactobacillus species. FEMS Microbiol. Lett. 205:31-36.

Gillespie, B. E., S. I. Headrick, S. Boonyayatra, and S. P. Oliver. 2009. Prevalence and persistence of coagulase-negative Staphylococcus species in three dairy research herds. Vet. Microbiol. 134:65-72.

Heikens, E., A. Fleer, A. Paauw, A. Florijn, and A. C. Fluit. 2005. Comparison of genotypic and phenotypic methods for species-level identification of clinical isolates of coagulase-negative staphylococci. J. Clin. Microbiol. 43:2286-2290.

Holm, C., L. Jepsen, M. Larsen, and L. Jespersen. 2004. Predominant microflora of downgraded Danish bulk tank milk. J. Dairy Sci. 87:1151-1157.

Huijps, K., S. De Vliegher, T. Lam, and H. Hogeveen. 2009. Cost estimation of heifer mastitis in early lactation by stochastic modelling. Vet. Microbiol. 134:121-127.

Iwamoto, T., K. Tani, K. Nakamura, Y. Suzuki, M. Kitagawa, M. Eguchi, and M. Nasu. 2000. Monitoring impact of in situ biostimulation treatment on groundwater bacterial community by DGGE. FEMS Microbiol. Ecol. 32:129-141.

Jones, T. O., and P. C. Turnbull. 1981. Bovine mastitis caused by Bacillus cereus. Vet. Rec. 108:271-274.

Kawai, M., E. Matsutera, H. Kanda, N. Yamaguchi, K. Tani, and M. Nasu. 2002. 16S ribosomal DNA-based analysis of bacterial diversity in purified water used in pharmaceutical manufacturing processes by PCR and denaturing gradient gel electrophoresis. Appl. Environ. Microbiol. 68:699-704.

Krömker, V., and J. Friedrich. 2009. Teat canal closure in non-lactating heifers and its association with udder health in the consecutive lactation. Vet. Microbiol. 134:100-105.

Magnusson, M., A. Christiansson, and B. Svensson. 2007. Bacillus cereus spores during housing of dairy cows: Factors affecting contamination of raw milk. J. Dairy Sci. 90:2745-2754.

Neijenhuis, F., H. W. Barkema, H. Hogeveen, and J. P. T. M. Noordhuizen. 2000. Classification and longitudinal examination of callused teat ends in dairy cows. J. Dairy Sci. 83:2795-2804.

NMC. 2012. NMC Factsheet-Postmilking teat disinfection (revised 2007). Accessed May 19, 2012. http://www.nmconline.org/postmilkingTD.htm. NMC (National Mastitis Council), Madison, WI.

Parsek, M. R., and P. K. Singh. 2003. Bacterial biofilms: An emerging link to disease pathogenesis. Annu. Rev. Microbiol. 57:677-701.

Piepers, S., L. De Meulemeester, A. de Kruif, G. Opsomer, H. W. Barkema, and S. De Vliegher. 2007. Prevalence and distribution of mastitis pathogens in subclinically infected dairy cows in Flanders, Belgium. J. Dairy Res. 74:478-483. 
Piepers, S., G. Opsomer, H. W. Barkema, A. de Kruif, and S. De Vliegher. 2010. Heifers infected with coagulase-negative staphylococci in early lactation have less cases of clinical mastitis and a higher milk production in their first lactation than non-infected heifers. J. Dairy Sci. 93:2014-2024.

Piepers, S., K. Peeters, G. Opsomer, H. W. Barkema, K. Frankena, and S. De Vliegher. 2011. Pathogen group specific risk factors at herd, heifer and quarter levels for intramammary infections in early lactating dairy heifers. Prev. Vet. Med. 99:91-101.

Piessens, V., E. Van Coillie, B. Verbist, K. Supré, G. Braem, A. Van Nuffel, L. De Vuyst, M. Heyndrickx, and S. De Vliegher. 2011. Distribution of coagulase-negative Staphylococcus species from milk and environment of dairy cows differs between herds. J. Dairy Sci. 94:2933-2944.

Pinzón-Sánchez, C., and P. L. Ruegg. 2011. Risk factors associated with short-term post-treatment outcomes of clinical mastitis. J. Dairy Sci. 94:3397-3410.

Pitkälä, A., M. Haveri, S. Pyörälä, V. Myllys, and T. Honkanen-Buzalski. 2004. Bovine mastitis in Finland 2001-Prevalence, distribution of bacteria, and antimicrobial resistance. J. Dairy Sci. 87:2433-2441.

Rajala-Schultz, P. J., K. L. Smith, J. S. Hogan, and B. C. Love. 2004. Antimicrobial susceptibility of mastitis pathogens from first lactation and older cows. Vet. Microbiol. 102:33-42.

Rasbash, J., C. Charlton, W. J. Browne, M. Healy, and B. Cameron. 2009. MLwiN Version 2.1. Centre for Multilevel Modelling, University of Bristol, Bristol, UK.

Roberson, J. R., L. K. Fox, D. D. Hancock, C. C. Gay, and T. E. Besser. 1994. Coagulase-positive Staphylococcus intramammary infections in primiparous dairy cows. J. Dairy Sci. 77:958-969.

Sampimon, O. C., H. W. Barkema, I. M. G. A. Berends, J. Sol, and T. J. G. M. Lam. 2009. Prevalence of intramammary infection in Dutch dairy herds. J. Dairy Res. 76:129-136.

Sampimon, O. C., T. J. G. M. Lam, D. J. Mevius, Y. H. Schukken, and R. N. Zadoks. 2011. Antimicrobial susceptibility of coagulasenegative staphylococci isolated from bovine milk samples. Vet. Microbiol. 150:173-179.

Schukken, Y. H., R. N. González, L. L. Tikofsky, H. F. Schulte, C. G Santisteban, F. L. Welcome, G. J. Bennett, M. J. Zurekowski, and R. N. Zadoks. 2009. CNS mastitis: Nothing to worry about? Vet. Microbiol. 34:9-14.

Sieber, R. L., and R. J. Farnsworth. 1981. Prevalence of chronic previous term teat-end lesions and their relationship to intramammary infection in 22 herds of dairy cattle. J. Am. Vet. Med. Assoc. 12:1263-1267.

Supré, K., F. Haesebrouck, R. N. Zadoks, M. Vaneechoutte, S. Piepers, and S. De Vliegher. 2011. Some coagulase-negative Staphylococcus species affect udder health more than others. J. Dairy Sci. 94:2329-2340.
Taponen, S., J. Björkroth, and S. Pyörälä. 2008. Coagulase-negative staphylococci isolated from bovine extramammary sites and intramammary infections in a single dairy herd. J. Dairy Res. 75:422429.

Taponen, S., J. Koort, J. Björkroth, H. Saloniemi, and S. Pyörälä. 2007. Bovine intramammary infections caused by coagulase-negative staphylococci may persist throughout lactation according to amplified fragment length polymorphism-based analysis. J. Dairy Sci. 90:3301-3307.

Taponen, S., H. Simojoki, M. Haveri, H. D. Larsen, and S. Pyörälä. 2006. Clinical characteristics and persistence of bovine mastitis caused by different species of coagulase-negative staphylococci identified with API or AFLP. Vet. Microbiol. 115:199-207.

Thorberg, B. M., M. L. Danielsson-Tham, U. Emanuelson, and K. Persson Waller. 2009. Bovine subclinical mastitis caused by different types of coagulase-negative staphylococci. J. Dairy Sci. 92:4962-4970.

Tulinski, P., A. C. Fluit, J. A. Wagenaar, D. Mevius, L. van de Vijver, and B. Duim. 2012. Methicillin-resistant coagulase-negative staphylococci on pig farms as a reservoir of heterogeneous staphylococcal cassette chromosome mec elements. Appl. Environ. Microbiol. 78:299-304.

Vasilopoulos, C., F. Ravyts, H. De Maere, E. De Mey, H. Paelinck, L. De Vuyst, and F. Leroy. 2008. Evaluation of the spoilage lactic acid bacteria in modified-atmosphere-packaged artisan-type cooked ham using culture-dependent and culture-independent approaches. J. Appl. Microbiol. 104:1341-1353.

Verdier-Metz, I., G. Gagne, S. Bornes, F. Monsallier, P. Veisseire, C. Delbès-Paus, and M.-C. Montel. 2012. Cow teat skin, a potential source of diverse microbial populations for cheese production. Appl. Environ. Microbiol. 78:326-333.

Woodward, W. D., T. E. Besser, A. C. Ward, and L. B. Corbeil. 1987. In vitro growth inhibition of mastitis pathogens by bovine teat skin normal flora. Can. J. Vet. Res. 51:27-31.

Zadoks, R. N., W. B. van Leeuwen, D. Kreft, L. K. Fox, H. W. Barkema, Y. H. Schukken, and A. van Belkum. 2002. Comparison of Staphylococcus aureus isolates from bovine and human skin, milking equipment, and bovine milk by phage typing, pulsed-field gel electrophoresis, and binary typing. J. Clin. Microbiol. 40:38943902 .

Zadoks, R. N., and J. L. Watts. 2009. Species identification of coagulase-negative staphylococci: Genotyping is superior to phenotyping. Vet. Microbiol. 134:20-28.

Zong, Z., C. Peng, and X. Lü. 2011. Diversity of SCCmec elements in methicillin-resistant coagulase-negative staphylococci clinical isolates. PLoS ONE 6:e20191. 